\title{
Interaction of cultured human endothelial cells with polymeric surfaces of different wettabilities
}

\author{
P.B. van Wachem, T. Beugeling, J. Feijen, A. Bantjes, J.P. Detmers* and \\ W.G. van Aken \\ Department of Chemical Technology, Twente University of Technology, P.O. Box 217, 7500 AE Enschede, The Netherlands \\ (Received 25 March 1985; revised 7 May 1985)
}

\begin{abstract}
The in vitro interaction of human endothelial cells (HEC) and polymers with different wettabilities in culture medium containing serum was investigated. Optimal adhesion of HEC generally occurred onto moderately wettable polymers. Within a series of cellulose type of polymers the cell adhesion increased with increasing contact angle of the polymer surfaces. Proliferation of HEC occurred when adhesion was followed by progressive flattening of the cells.

Our results suggest that moderately wettable polymers exhibit a serum and/or cellular protein adsorption pattern that is favourable for growth of HEC.
\end{abstract}

Keywords: Polymer surface, cells (human endothelial), adhesion, proliferation, wettability

Synthetic polymers such as Dacron ${ }^{\circledast}$ [PETP, poly(ethylene terephthalate)] are sucessfully used for vascular grafts with a relatively large inner diam. $(\geqslant 4 \mathrm{~mm})$. Before insertion, such grafts are usually preclotted with blood to prevent leakage, leaving a rather thrombogenic surface. High blood flow and anticoagulant therapy may prevent occlusion due to further thrombus formation on the graft surface. Thereafter, in- and overgrowth of perigraft tissue will alter the surface of the graft, but the biological lining created is hardly nonthrombogenic ${ }^{1,2}$.

The clinical results with small diameter grafts (inner diam. $\leqslant 4 \mathrm{~mm}$ ) are in general disappointing, mainly because of immediate occlusion of the grafts.

Since vascular endothelium represents a unique nonthrombogenic surface, endothelial cells are the first logical choice for lining small diameter vascular grafts. In dogs. seeding of endothelial cells onto both large and small diameter grafts was shown to result in a complete endothelial lining between 1 and 4 mnth $^{3}$.

A systematic study of the interaction of endothelial celis and polymers with different surface properties may lead to the development of grafts which promote overgrowth of endothelial cells.

It has been demonstrated that surface wettability influences adhesion and proliferation of different types of mammalian cells. Cell adhesion occurred preferentially to water wettable substrates ${ }^{4}$.

When serum is present in the culture medium, cell adhesion to wettable substrates seems to be influenced by the adsorption of serum proteins onto these substrates ${ }^{5}$.

*Hospital Ziekenzorg, Enschede, The Netherlands.
If cell adhesion is studied in serum-free medium, the absorption of protein(s) originating from the cells onto wettable substrates may be of importance ${ }^{6}$.

Like other cell types endothelial cells can be cultured on glass and wettable tissue culture polystyrene, which is a glow discharge treated polystyrene. Bovine endothelial cells have been reported to grow on polyacrylamide beads ${ }^{7}$ and on sulphonated polystyrene beads ${ }^{8}$. Furthermore, these cells grow upon crosslinked dextran beads precoated with collagen $^{9}$. The presence of collagen is also needed for growth upon the very hydrophilic polyHEMA ${ }^{10}$. Poor growth of bovine endothelial cells was found upon the polyurethane Biomer, unless Biomer was precoated with gelatin or an extracellular matrix ${ }^{11}$. Little is known, however, about the behaviour of (human) endothelial cells and other materials. We have previously presented preliminary data about the interaction of cultured human endothelial cells (HEC) with several polymeric surfaces ${ }^{12}$.

In the present study, we have examined the in vitro adhesion and proliferation of HEC on(to) a number of polymers with different wettabilities in culture medium containing serum.

\section{MATERIALS AND METHODS}

\section{Cell culture}

Endothelial cells were isolated from human umbilical cord veins according to the method of Jaffe et al. ${ }^{13}$ with some modifications $^{14}$. The cells were routinely cultured in tissue culture polystyrene (TCPS) flasks (Corning, New York, USA) 
precoated with a partially purified human plasma fibronectin, $\mathrm{Fn}^{\mathrm{c}}\left(2 \mathrm{mg} / \mathrm{ml} ; \mathrm{Fn}^{\mathrm{c}}\right.$ is a coproduct obtained during purification of human Factor VIII, Central Laboratory of the Netherlands Red Cross Blood Transfusion Service, Amsterdam, The Netheriands). The culture medium consisted of $50 \%$ Medium 199 and 50\% Medium RPMI (both from Gibco Biocult Co., Paisley, UK), supplemented with 20\% human serum (pool of 20 healthy male donors), $2 \mathrm{mM}$ of L-glutamine (Merck, Darmstadt, FRG), $100 \mathrm{U} / \mathrm{ml}$ of penicillin, $100 \mu \mathrm{g} / \mathrm{ml}$ of streptomycin (both from Flow Lab., Invine, UK) and $2.5 \mu \mathrm{g} / \mathrm{ml}$ of fungizone (Gibco).

Morphologically, endothelial cells form a confluent monolayer of small polygonal cells in contrast with the multilayers of smooth muscle cells and the monolayer of the elongated fibroblasts with overlap at the offshoots of the cells. Ultrastructurally, endothelial cells were distinguished from smooth muscle cells and fibroblasts by the presence of the so-called Weibel-Palade bodies ${ }^{15}$. Endothelial cells were further characterized by their specificity of producing F VIIIrelated antigen, which can be detected by fluorescent antibodies in distinct granula. Moreover, the endothelial cells were found to produce prostacyclin $\left(\mathrm{PGI}_{2}\right)^{16}$.

Experiments were carried out with cells harvested after the second or third passage when the culture had reached confluency.

\section{Cell adhesion and proliferation}

Endothelial cells were harvested after trypsin treatment (0.05\% trypsin/0.02\% EDTA, Gibco). Next trypsin was inactivated by the addition of the serum containing culture medium.

Cell adhesion to surfaces was determined at various time intervals $(30 \mathrm{~min}, 1,2$ and $6 \mathrm{~h})$ after seeding $4 \times 10^{4}$ cells $/ \mathrm{cm}^{2}$. Before harvesting the adherent cells (by trypsinization) and cell counting, two washings with phosphate buffered saline $\left(8.2 \mathrm{~g} / / \mathrm{NaCl}, 3.1 \mathrm{~g} / 1 \mathrm{Na}_{2} \mathrm{HPO}_{4} .12 \mathrm{H}_{2} \mathrm{O}\right.$, $0.2 \mathrm{~g} / / \mathrm{NaH}_{2} \mathrm{PO}_{4} .2 \mathrm{H}_{2} \mathrm{O} ; \mathrm{pH}$ 7.4) were performed.

Cells were counted using a haemocytometer. For adhesion experiments, the 13 materials were divided into 2 groups. Each group was tested with a separate endothelial cell culture and TCPS precoated with $\mathrm{Fn}^{\mathrm{C}}$ (reference material) was included in both groups. The number of cells adhering to a material was expressed as the percentage of the cells adhering to TCPS precoated with $\mathrm{Fn}^{\mathrm{c}}$ at a certain time. Data are presented as the mean values of three counts. Cell proliferation upon the surfaces was determined in a similar way as already mentioned. Time intervals of $2,4,6$ and $8 \mathrm{~d}$ were taken after seeding $1 \times 10^{4}$ cells $/ \mathrm{cm}^{2}$.

The volume of the culture medium in the test chamber was adjusted so that the ratio between this volume (in $\mathrm{ml}$ ) and the test surface area (in $\mathrm{cm}^{2}$ ) of the polymer was 0.2 .

The culture medium in the test chambers, which were not used for cell counting, was refreshed at day 2,4 and 6 .

\section{Materials}

The polymers used were obtained as set out in Table $M$. PETP, PMMA, PC, FEP and glass were cleaned ultrasonically in a $1 \%(\mathrm{v} / \mathrm{v})$ detergent solution (RBS 25, Hicol, Rotterdam, The Netherlands) for $\mathbf{3 0} \mathrm{min}$, followed by extensive rinsing with distilled water and ethanol. CE and the 'home-made" films PS, PLLA, PUR, CA2.5 and CA3 were also extensively rinsed with distilled water.

PETP, PC, FEP and glass were sterilized by autoclaving; PS, PLLA, PUR and CE were gas-sterilized by ethylene oxide, PMMA by formaldehyde, CA 2.5 and CA 3 were sterilized by
Table $M$

\begin{tabular}{|c|c|}
\hline Abbreviations & Materials \\
\hline TCPS & $\begin{array}{l}\text { Tissue culture polystyrene, Costar, Cambridge MA, } \\
\text { USA, (6-well culture cluster) }\end{array}$ \\
\hline PS & $\begin{array}{l}\text { Polystyrene, Chemical Pressure Co., Pittsburgh PA. } \\
\text { USA, [films cast from a } 10 \% \text { solution }(w / w) \text { in toluene] }\end{array}$ \\
\hline TCPETP & $\begin{array}{l}\text { Tissue culture poly(ethylene terephthalate), Becton } \\
\text { Dickinson, Oxnard CA, USA, (Falcon-film lined dish) }\end{array}$ \\
\hline PETP & $\begin{array}{l}\text { Poly(ethylene terephthalate), ICl, Rotterdam, The } \\
\text { Netherlands, (Melinex polyester film, type O) }\end{array}$ \\
\hline PMMA & $\begin{array}{l}\text { Poly(methyl methacrylate), Röhm, Darmstadt GmbH. } \\
\text { FRG, (type CS-233) }\end{array}$ \\
\hline $\mathrm{PC}$ & $\begin{array}{l}\text { Polycarbonate, General Electric Plastics, Bergen op Zoom, } \\
\text { The Netherlands (Lexan type 9034-112) }\end{array}$ \\
\hline FEP & $\begin{array}{l}\text { Fluoroethylenepropylene copolymer, Du Pont de } \\
\text { Nemours, Geneva, Switzerland (film type 500A) }\end{array}$ \\
\hline PLLA & $\begin{array}{l}\text { Poly-L-lactic acid, [films cast from a } 4 \% \text { solution ( } w / w \text { ) } \\
\text { in chloroform, kindly supplied by ir. M.J.D. Eenink from } \\
\text { our laboratory] }\end{array}$ \\
\hline PUR & $\begin{array}{l}\text { Polyurethane, Ethicon Co. Sommerville } \mathrm{NJ}, \text { USA, } \\
\text { [Biomer, films cast from a } 10 \% \text { solution }(w / w) \text { in dimethyl- } \\
\text { acetamide] }\end{array}$ \\
\hline CE & Cellophane, Enka, Wuppertal, FRG, (Cuprophane PT 150) \\
\hline CA2.5 & $\begin{array}{l}\text { Cellulose-2.5-acetate, Fabelta SA, Tubize, Belgium, [films } \\
\text { cast from a } 10 \% \text { solution }(w / w) \text { in acetone, type TV 20] }\end{array}$ \\
\hline CA3 & $\begin{array}{l}\text { Cellulose-3-acetate, Fluka AG, Buchs, Switzerland [films } \\
\text { cast from a } 10 \% \text { solution }(w / w) \text { in tetrachloride ethane] }\end{array}$ \\
\hline Glass & Hard glass, Corning. New York, USA (type 7059) \\
\hline
\end{tabular}

$\gamma$-irradiation (2.5 Mrad, Gammaster, Ede, The Netherlands). TCPS and TCPETP were used as received from the manufacturer.

All surfaces were transparent to allow for light microscope examination.

\section{Contact angle measurements}

Contact angles were measured by means of the captive bubble method ${ }^{17}$. The air bubble was photographed in distilled water of $21^{\circ} \mathrm{C}$ within $30 \mathrm{~s}$ after contact with the polymer surface.

The contact angle was taken as $\theta=180^{\circ}-2 \operatorname{arctg} 2 \mathrm{~h} / \mathrm{b}$ in which $h$ and $b$ are height and width of the airbubble respectively. (Data are presented as the mean values of five measurements).

\section{Test chamber}

Specimens $(4 \times 4 \mathrm{~cm})$ of the material were mounted into a modified 'Bionique' growth chamber (Corning. New York, USA); (see Figure 1).

The chamber is composed of:

(i) a stainless steel bottom plate (thickness $1.0 \mathrm{~mm}$ ) with welded-on screw pins and a cylindrical hole of $25.2 \mathrm{~mm}$ diam.;

(ii) a sealing ring of Viton rubber;

(iii) a Teflon upper part (thickness $10.0 \mathrm{~mm}$ ) with a cylindrical hole of $25.2 \mathrm{~mm}$ diam. provided with a stepped recess in which the Viton sealing ring fits (bottom side) and a groove (top side) for a Petri dish cover (tissue culture polystyrene; diam. $37.6 \mathrm{~mm}$ ).

The chamber can be gas- and steam sterilized and is put together with wing nuts. The test surface area is $5 \mathrm{~cm}^{2}$. 

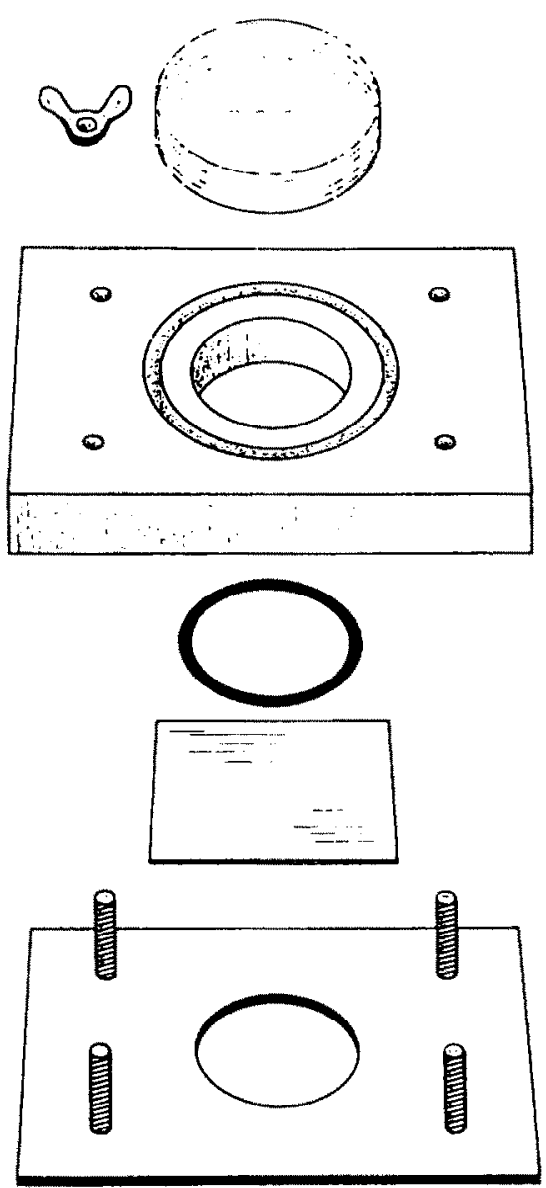

Figure 1 Test chamber for testing the interaction between polymers and HEC. The stain/ess steel bottom plate and the Teflon upper part, with the test polymer and the Viton rubber sealing ring in between, are put together with wing nuts and covered with a Petri dish lid.

\section{RESULTS}

Previous experiments with human endothelial cell cultures indicated that TCPS precoated with fibronectin provides a surface upon which endothelial cells readily adhere in a very reproducible way ${ }^{15}$. Therefore this surface was selected as 'reference' surface for other (non-precoated) materials used in this study.

When TCPS coated with $\mathrm{Fn}^{\mathrm{c}}$ was used, $78.5 \pm 13.4 \%$ $(n=9$ ) of the seeded HEC adhered within $30 \mathrm{~min}$; upon adhesion, the cells showed microscopically a progressive flattening. After $6 \mathrm{~h}, 91.4 \pm 10.3 \%$ of the cells had adhered and spread on the surface (not shown).

All the materials tested showed a slower adhesion rate of HEC as compared with TCPS precoated with $\mathrm{Fn}^{\mathrm{c}}$ (Table 1, Figure 2). At $30 \mathrm{~min}$ after seeding about $45 \%$ of the cells adhered to TCPS and TCPETP, resulting in an adhesion percentage of $85 \%$ at $6 \mathrm{~h}$. Spreading of adherent cells was similar to the spreading of cells on TCPS precoated with $\mathrm{Fn}^{\mathrm{c}}$. When PETP, PMMA, PC, glass, CA3 and PUR were used, only $38-70 \%$ of HEC adhered after $6 \mathrm{~h}$. The adherent HEC showed a spider-like structure. Progressive flattening of cells was only observed on glass. When HEC were seeded onto CA2.5, PLLA, FEP and PS only few HEC showed adherence over a period of $6 \mathrm{~h}$ and the remaining cells were floating. In the case of CE no adhesion was seen microscopically and all cells were floating.

Contact angles of the materials are shown in Table 2. CE was found to be the most hydrophilic polymer with a contact angle of $16^{\circ}$ (only glass was more hydrophilic than this polymer), and FEP was the most hydrophobic polymer with a contact angle of $102^{\circ}$.

TCPS and TCPETP, with contact angles of $35^{\circ}$ and $44^{\circ}$ respectively, are moderately wettable polymers. Esterification of $\mathrm{OH}$-groups in $\mathrm{CE}$, with 2.5 esterified $\mathrm{OH}$-groups per monomeric unit in $\mathrm{CA} 2.5$ and 3 esterified $\mathrm{OH}$-groups in $\mathrm{CA} 3$ resulted in a change of the contact angle from $16^{\circ}$ to $31^{\circ}$ and $52^{\circ}$ respectively.

In Figure 3 the adhesion of HEC after 2 and $6 \mathrm{~h}$ is plotted as a function of the contact angle. Several moderately wettable surfaces showed a good adhesion of HEC. Both more hydrophilic and more hydrophobic polymers showed poor adhesion of HEC, PC being the main exception in the last category. Increase of cell adhesion with increasing

Table 1 Adhesion of HEC to polymers and glass. (See Figure 2)

\begin{tabular}{lcccrrr}
\hline Polymer & $30 \mathrm{~min}$ & $1 \mathrm{~h}$ & $2 \mathrm{~h}$ & $6 \mathrm{~h}$ \\
\hline TCPS & $43 \pm 6$ & $59 \pm 6$ & $76 \pm 10$ & $83 \pm 8$ \\
PS & $20 \pm 2$ & $14 \pm 1$ & $14 \pm 3$ & $3 \pm 1$ \\
TCPETP & $44 \pm 6$ & $54 \pm 12$ & $70 \pm 5$ & $86 \pm 16$ \\
PETP & $19 \pm 3$ & $31 \pm 1$ & $48 \pm 8$ & $38 \pm 4$ \\
PMMA & $18 \pm 4$ & $19 \pm 6$ & $25 \pm 4$ & $42 \pm 4$ \\
PC & $19 \pm 4$ & $39 \pm 10$ & $51 \pm 10$ & $49 \pm 5$ \\
FEP & $5 \pm 3$ & $8 \pm 6$ & $9 \pm 4$ & $7 \pm 1$ \\
PLLA & $8 \pm 2$ & $10 \pm 3$ & $19 \pm 3$ & $11 \pm 5$ \\
PUR & $24 \pm 11$ & $25 \pm 4$ & $37 \pm 8$ & $69 \pm 3$ \\
CE & 0 & 0 & & 0 & 0 \\
CA2.5 & $7 \pm 1$ & $16 \pm 8$ & $30 \pm 4$ & $24 \pm 4$ \\
CA3 & $38 \pm 7$ & $41 \pm 10$ & $60 \pm 8$ & $66 \pm 9$ \\
Glass & $10 \pm 2$ & $18 \pm 9$ & $43 \pm 8$ & $59 \pm 18$ \\
\hline
\end{tabular}

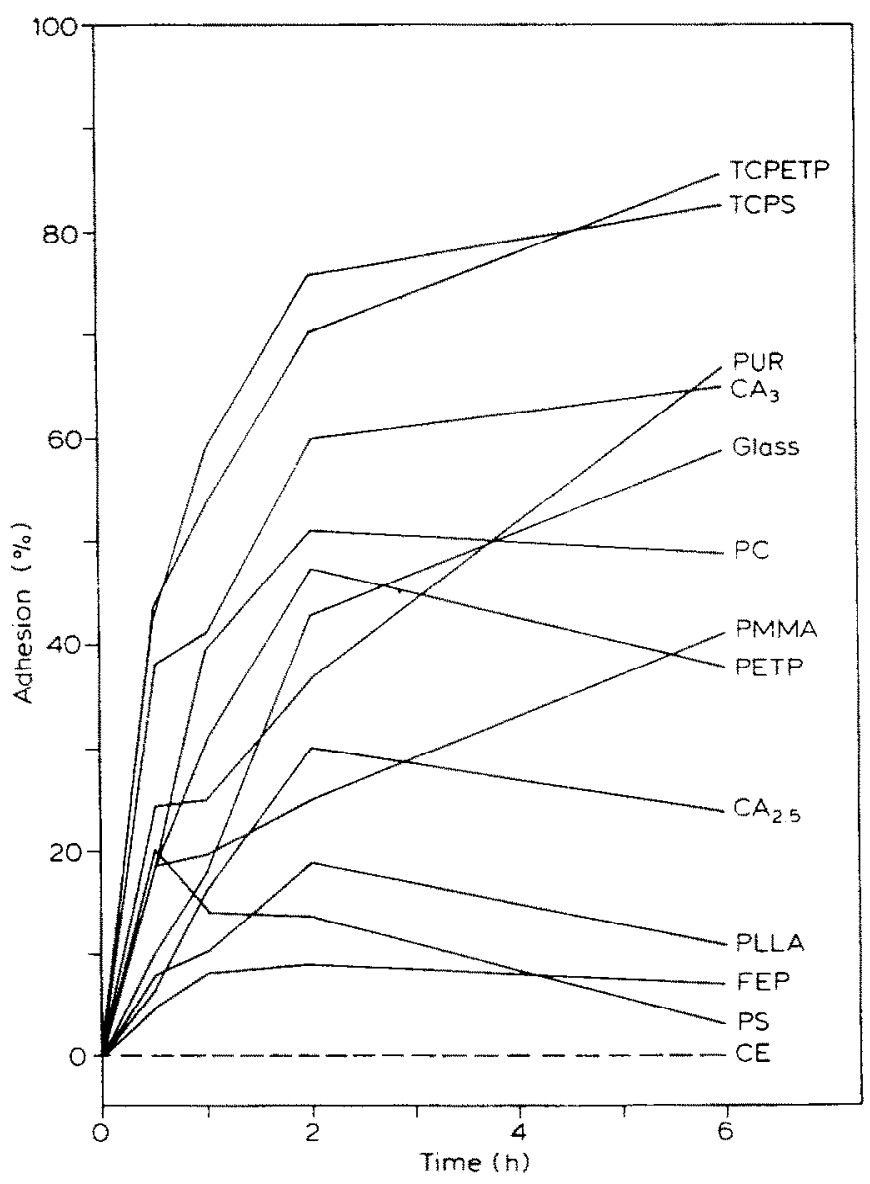

Figure 2 Adhesion of HEC to polymers and glass. $4 \times 10^{4} \mathrm{cells} / \mathrm{cm}^{2}$ in serum containing culture medium were seeded upon the test surfaces. Cell cuuntings at 30 min, 1,2 and 6 h were expressed as percentages of countings of adherent cells on TCPS precoated with $\mathrm{Fn}^{c}$. In the case of CE no adhesion was seen microscopically. 
Table 2 Contact angle $\theta\left(^{\circ}\right)$ of polymer surfaces, determined with the captive bubble method

\begin{tabular}{lr}
\hline Polymer surface & $\theta\left(^{\circ}\right)$ \\
\hline TCPS & $35 \pm 3$ \\
PS & $77 \pm 2$ \\
TCPETP & $44 \pm 2$ \\
PETP & $65 \pm 2$ \\
PMMA & $61 \pm 3$ \\
PC & $83 \pm 2$ \\
FEP & $102 \pm 2$ \\
PLLA & $71 \pm 3$ \\
PUR & $37 \pm 2$ \\
CE & $16 \pm 2$ \\
CA2.5 & $31 \pm 4$ \\
CA3 & $52 \pm 1$ \\
Glass & $13 \pm 3$ \\
\hline
\end{tabular}

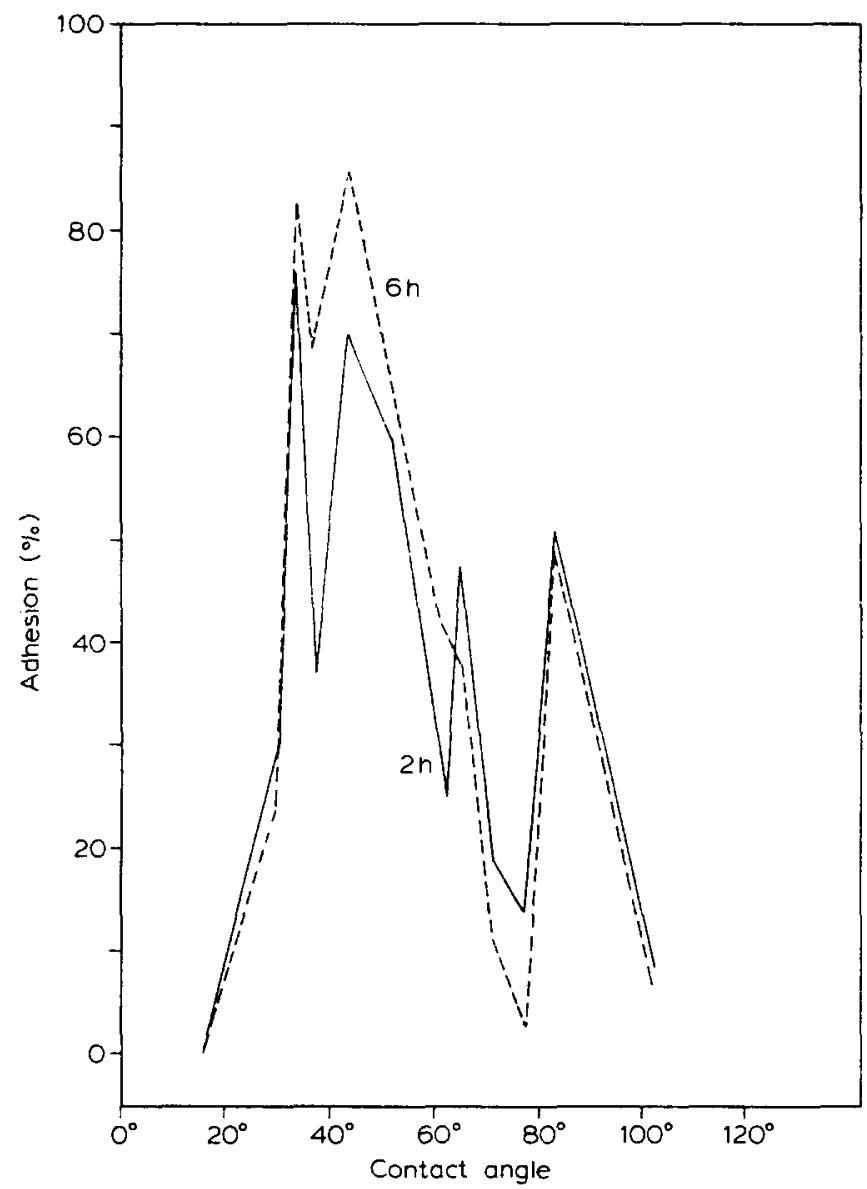

Figure 3 Adhesion of HEC in serum containing culture medium as a function of polymer contact angle. Cell counting was carried out after $2(-$ land $6 \mathrm{~h}$ $(--)$ and compared with the adhesion of HEC to TCPS precoated with Fn'.

contact angles was observed for the polymer series $C E$, CA2.5 and CA3. At $6 \mathrm{~h}$ after cell seeding the adhesion percentage was $0,23.9$ and 65.5 respectively (Figure 4).

Upon adhesion and spreading of HEC to the polymer surfaces, proliferation started on TCPS, TCPETP and glass (Figure 5, Table 3). On TCPS a density of more than $10 \times$ $10^{4}$ cells $/ \mathrm{cm}^{2}$ was reached at $8 \mathrm{~d}$. Proliferation on TCPETP and glass was about the same as found for the control surface and also PC with a density of about $6.5 \times 10^{4} \mathrm{cells} / \mathrm{cm}^{2}$ showed this behaviour. The proliferation of HEC on PC started from cell clusters, where the initial spider-like structure of the cells soon changed into a spread structure. In time single cells died and detached from the surface.

At $8 \mathrm{~d}$ a minor cell proliferation occurred on CA3, PMMA, PETP, and PUR as compared to the preceding days.
Again, microscopic examination showed that proliferation started from cell clusters.

HEC failed to proliferate on CA2.5, PLLA, PS, FEP and $\mathrm{CE}$.

\section{Discussion}

The results of this study demonstrate that optimal adhesion of HEC from serum containing culture medium to polymers occurs with surfaces showing a moderate wettability. Both more hydrophilic and more hydrophobic polymers showed less or no adhesion. However, a relationship between cel adhesion and wettability was not found when a variety of polymers was used. A homologous series of the CE-type of polymers in which the conversion of hydroxyl groups into acetate groups caused changes in the wettability, showed an increase of cell adhesion with increasing contact angle.

Whether or not cell adhesion and proliferation occur, depends on the surface properties of the polymer. Since these experiments were performed in the presence of $20 \%$ human serum, the surface properties of the polymers influence the adhesion of HEC via their adsorption properties with respect to serum proteins. The adsorbed protein layer

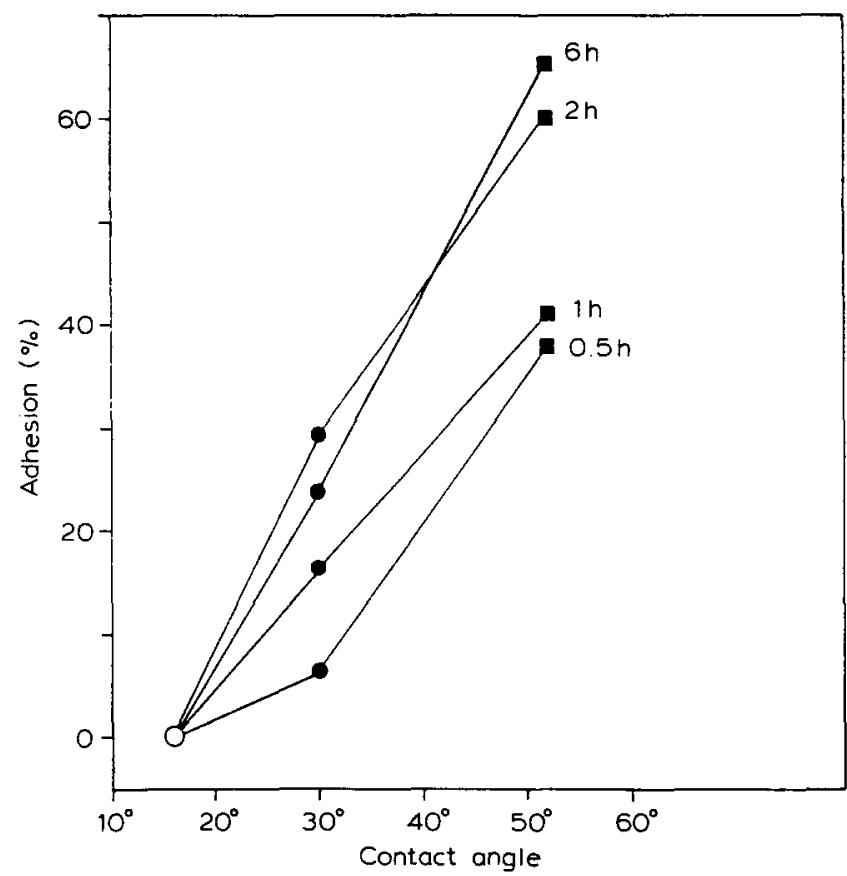

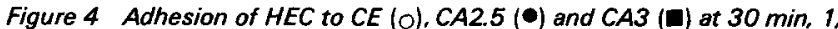
2 and $6 h$ as a function of the contact angle of these polymers. Results were compared with the adhesion of HEC to TCPS precoated with $\mathrm{Fn}^{c}$.

Table 3 Proliferation of HEC on polymers and glass. (See Figure 5)

\begin{tabular}{lcccc}
\hline Polymer & $2 \mathrm{~d}$ & $\mathbf{4 d}$ & $\mathbf{6 d}$ & $\mathbf{8 d}$ \\
\hline TCPS & $\mathbf{1 9} \pm \mathbf{4}$ & $49 \pm 12$ & $84 \pm 12$ & $102 \pm 12$ \\
PS & 0 & 0 & 0 & 0 \\
TCPETP & $15 \pm 3$ & $\mathbf{3 9} \pm \mathbf{8}$ & $\mathbf{4 5} \pm 10$ & $66 \pm 5$ \\
PETP & $10 \pm 1$ & $11 \pm 5$ & $16 \pm 6$ & $15 \pm 8$ \\
PMMA & $\mathbf{8} \pm 2$ & - & - & $16 \pm 1$ \\
PC & $13 \pm 6$ & $33 \pm 9$ & - & $65 \pm 11$ \\
FEP & 0 & 0 & 0 & 0 \\
PLLA & 0 & 0 & 0 & 0 \\
PUR & $9 \pm 1$ & $7 \pm 1$ & $6 \pm 2$ & $13 \pm 1$ \\
CE & 0 & 0 & 0 & 0 \\
CA2.5 & 0 & 0 & 0 & 0 \\
CA3 & $10 \pm 2$ & $9 \pm 1$ & $9 \pm 3$ & $22 \pm 10$ \\
Glass & $18 \pm 3$ & $47 \pm 10$ & $67 \pm 14$ & $65 \pm 10$ \\
TCPS-Fn & & & \\
& $19 \pm 2$ & $50 \pm 4$ & 52 & $56 \pm 8$
\end{tabular}




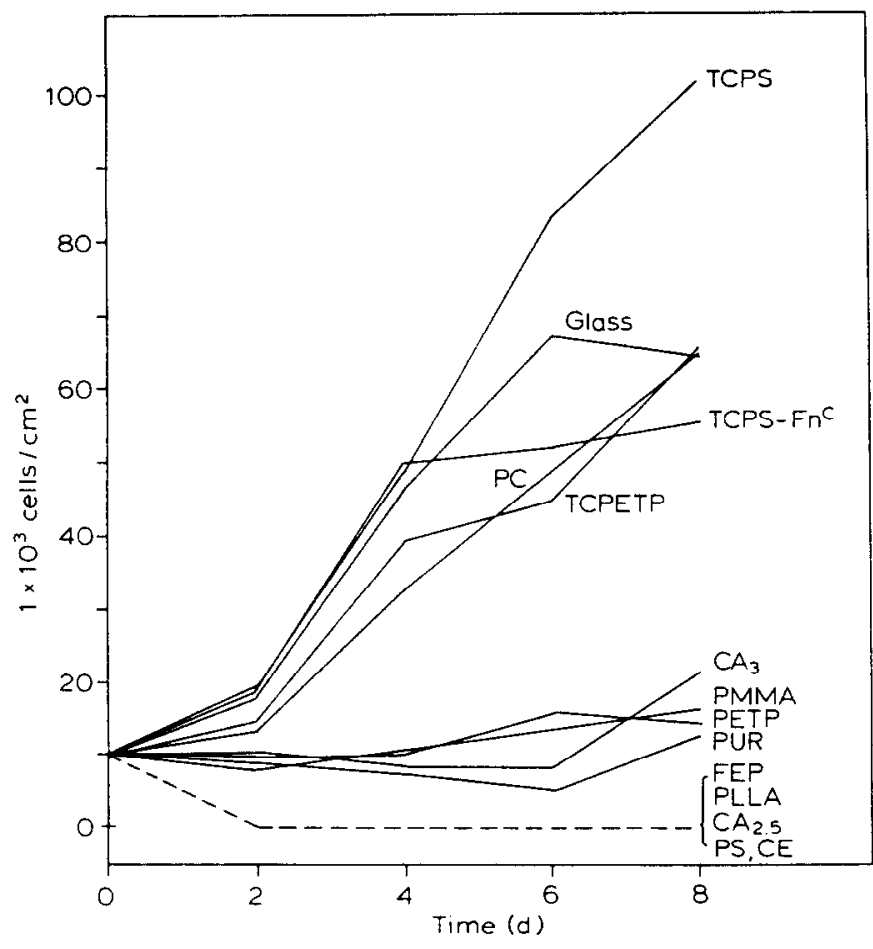

Figure 5 Proliferation of HEC on polymers and g/ass. $1 \times 10^{4} \mathrm{cel} / \mathrm{s} / \mathrm{cm}^{2}$ in serum containing culture medium were seeded upon the test surfaces. Cell countings and refreshing of the culture medium were carried out at $2,4,6$ and $8 \mathrm{~d}$. The ratio of the culture medium $(\mathrm{ml})$ to the surface $\left(\mathrm{cm}^{2}\right)=0.2$. HEC failed to proliferate on FEP, PLLA, CA2.5, PS and CE.

on TCPS and TCPETP probably has a more favourable or less inhibiting composition and/or conformation for cell adhesion as compared to more hydrophobic and more hydrophilic polymers. Only small amounts of protein adsorb to hydrophilic polymers like CE, which swell in water. Moreover, such polymers show reversible protein adsorption ${ }^{18}$ and this accounts for the fact that precoating of CE with $\mathrm{Fn}^{\mathrm{c}}$ (in order to improve cell adhesion) was not effective (unpublished results). Presumably $\mathrm{Fn}^{\mathrm{c}}$ is rapidly desorbed when precoated $\mathrm{CE}$ is exposed to the culture medium.

In view of the foregoing it is not surprising that the hydrophilic polyHEMA also does not show adhesion of $\mathrm{HEC}^{\dagger 0}$. Glass is also hydrophilic, nevertheless, HEC adhered to and spread on this material. Protein adsorption has been observed on glass ${ }^{18}$ which subsequently may mediate cell adhesion. HEC adhered to PUR, like TCPS a moderately wettable polymer, but the cells did not spread and only a minor proliferation was observed at $8 \mathrm{~d}$. Poor growth of endothelial cells on PUR (Biomer) was reported before, in this case for endothelial cells of bovine origin ${ }^{11}$.

Cytotoxic effects of 'home-made' films and CE, which could in theory account for reduced cell adhesion and proliferation, seem unlikely for the following reasons: firstly, the materials were extensively rinsed in distilled water before being tested and, secondly, floating cells which were removed after $6 \mathrm{~h}$ of incubation with these materials still adhered and proliferated after seeding onto TCPS precoated with $\mathrm{Fn}^{\mathrm{c}}$.

Since fibronectin is present in serum, this protein might have adsorbed onto TCPS. Baby hamster kidney (BHK) cells and leucocytes adhere well to hydroxylated polystyrene (a TCPS) ${ }^{19}$. Curtis and Forrester ${ }^{20}$ suggest that the increased adsorption of fibronectin, in combination with a decreased adsorption of serum albumin, a-1-antitrypsin and $a$-2-macroglobulin to hydroxylated polystyrene as compared to nonhydroxylated PS is the reason for this result.
However, Grinnell ${ }^{21}$ showed that fibronectin adsorption from serum containing solutions to polymers is decreased markedly at serum conc. above $1.0 \%$. This author did not observe a difference in fibronectin adsorption between PS and TCPS at higher serum concentrations. This supports the suggestion of $\mathrm{Knox}^{22}$ that fibronectin is not involved in the serum-stimulated $\mathrm{BHK}$ cell spreading at a serum concentration of $3 \%$ or higher. He found that rates of cell spreading were identical whether fibronectin was present or not.

Therefore, it is not yet clear if the low fibronectin adsorption from the culture medium containing $20 \%$ human serum is involved in the adhesion of HEC to TCPS (and TCPETP).

However, adsorbed fibronectin, originating from the cells seems to be important. Like other cell types endothelial cells produce fibronectin ${ }^{23}$ and the extracellular matrix has been shown to be composed predominantly of fibronectin and collagen ${ }^{24}$. After trypsinization of the cells, production of fibronectin [and/or other spreading protein(s)] may take some time. This may account for the delay in adhesion rate measured after half an hour in which only $45 \%$ of the cells had adhered to TCPS as compared to TCPS precoated with $\mathrm{Fn}^{\mathrm{c}}$. Presumably, the adsorbed serum protein layer on moderately wettable polymers permits the cells to produce and deposit their own adhering/spreading protein(s). A possible mechanism is that moderately wettable polymers show an exchange of surface bound proteins for cell secreted proteins. Such a process is expected to proceed at a slower rate in the cases of more hydrophobic polymers ${ }^{18}$

When cell adhesion was followed by progressive flattening of the cells, proliferation occurred (TCPS, TCPETP, glass). Progressive flattening seems to be a prerequisite for cell proliferation. This is not surprising because the shape of several types of nontransformed cells (including bovine endothelial cells) is linked to DNA synthesis ${ }^{25}$.

Progressive flattening of HEC was not observed upon PC. Only when many cells had adhered closely together (cell cluster) the spider-like cell structure upon PC changed in time to a more spread shape. The present proliferation data with respect to PC were not always reproducible. This indicates that the initial cell density necessary for proliferation is very critical in the case of PC.

Our results suggest that moderately wettable polymers give rise to a specific serum adsorption which is favourable for adhesion, spreading and proliferation of HEC.

\section{ACKNOWLEDGEMENT}

We thank Miss L.M. Rotman for typing the manuscript.

\section{REFERENCES}

1 Lindenauer, S.M., Experimental evaluation of Dacron knitted vascular grafts in Biological and synthetic vascular prostheses, (Ed. J.C. Stanley) Grune and Stratton, New York, 1982, p 523

2 Roon, A.J., Moore, W.S., Goldstone, J. et al., Comparative surface thrombogenicity of implanted vascular grafts, J. Surg. Res. 1977, 22, 165

3 Burkel, W.E., Ford, J.W., Vinter, D.W., Kahn, R.H., Graham, L.M. and Stanley, J.C., Endothelial seeding of enzymatically derived and cultured cells on prosthetic grafts in Biologic and synthetic vascular prostheses, (Ed. J.C. Stanley), Grune and Stratton, New York 1982, p 631

4 Grinnell, F., Cellular adhesiveness and extracellular substrata, Int. Rev. Cytol. 1978, 53,65

5 Baier, R.E., Shafrin, E.G. and Zisman, W.A., Science 1968, 162, 1360

6 Grinnell, F. and Feld, M.K., Initial adhesion of humlan fibroblasts in serum-free medium: possible role of secreted fibronectin, Cell 1979 , 17, 117 
7 Ryan, U.S., Mortara, M. and Whitaker, C., Methods for bovine pulmonary artery endothelial cells avoiding the use of enzymes. Tissue $\theta$ Cell $1980,12,619$

8 Jacobson, B.S. and Ryan, U.S., Growth of endothelial and HeLa cells on a new multipurpose microcarrier that is positive, negative or collagen coated, Tissue \& Cell 1982, 14,69

9 Busch, C., Cancilla, P.A., Debault, L.E., Goldsmith, J.C. and Owen, W.G., Methods in laboratory investigation. Use of endothelium cultured on microcarriers as a model for the microcirculation, Lab. Invest. 1982, 47, 498

10 Faris, B., Mozzicato, P., Mogayzal, P.J., Ferrera, R. Gerstenfeld, L.C. Glembourtt, M., Makarski, J.S., Haudenschild, C.C and Franzblau, C., Effect of protein-hydroxyethyl methacrylate hydrogels on cultured endothelial cells, Exp. Cell. Res. 1983, 143, 15

11 Nichols, W.K., Gospodarowicz, D., Kessler, T.R. and Olsen, D.B., Increased adherence of vascular endothelial cells to Biomer precoated with extracellular matrix, Trans. Am. Soc. Artif. Intern. Organs 1981. 27. 208

12 Van Wachem, P.B., Beugeling, T., Feijen, J., Bantjes, A., Detmers, J.P. and Van Aken, W.G., Life Support Systems, Proc. XI Annual Meeting ESAO, Alpbach-Innsbruck, Austria, September 1984, Saunders 1984, pp 98-112

13 Jaffe, E.A., Nachman, R.L., Becker, C.G. and Minick, C.R., Culture of human endothelial cells derived from umbilical veins. Identification by morphologic and immunologic criteria, J. Clin. Invest. 1973, 52, 2745

14 Willems, Ch. Astaldi, G.C.B., de Groot, Ph.G. Janssen, M.C. Gonsalves, M.D., Zeijlemaker, W.P., Van Mourik, J.A. and Van Aken, W.G., Media conditioned by cultured vascular endothelial cells inhibit the growth of vascular smooth muscle cells, Exp. Cell. Res.
$1982,139,191$

15 Weibel, E.R. and Palade, G.E., New cytoplasmic components in arteria endothelia, J. Cell. Biol. 1964, 23, 101

16 Willems, Ch., Metabolism of cultured vascular endothelial cells PhD Thesis Amsterdam, 1982

17 Andrade, J.D., King, R.N., Gregonis, D.E. and Coleman, D.L., Surface characterization of poly(hydroxyethyl methacrylate) and related polymers. 1. Contact angle methods in water, J. Polym. Sci: Polym Symp. 1979, 66, 313

18 Feijen, J., Beugeling, T., Bantjes, A, and Smit Sibinga, C.Th. Biomaterials and interfacial phenomena, AN, Candiovasc. Physics $1979,3,100$

19 Curtis, A.S.G., Forrester, J.V., Mclnnes, C. and Lawrie, F., Adhesion of cells to polystyrene surfaces, J. Cell. Biol. 1983, 97, 1500-1506

20 Curtis, A.S.G., Forrester, J.V., The competitive effects of serum proteins on cell adhesion, J. Cell. Sci. 1984, 71, 17-35

21 Grinnell, F., Fibronectin adsorption on hydrophilic and hydrophobic surfaces detected by antibody binding and analyzed during cell adhesion in serum containing medium, J. Biol. Chom. 1982, 257, 4888-4893

22 Knox, P., Kinetics of cell spreading in the presence of different concentrations of serum or fibronectin depleted serum, J. Cell. ScI. 1984, 71, 51-59

23 Jaffe, E.A., Synthesis of fibronectin by cultured human endothelial cells, J. Exp. Med. 1978, 147, 1779-1791

24 Gospodarowicz, D. and Tauber, J.P., Growth factors and the extracellular matrix, Endocrinal. Rev. 1980, 1, 201

25 Folkman, J. and Moscona, A., Role of cell shape in growth control Nature 1978, 273, 345 